\title{
KONTROL TERHADAP TUBUH PEREMPUAN PADA PRAKTIK REJUVENASI VAGINA
}

\author{
CONTROL OF WOMEN'S BODY \\ ON VAGINAL REJUVENATION PRACTICES
}

\author{
*Angela Frenzia Betyarini \\ Resource Center on Gender, Sexuality, and Human Rights Studies Udayana Bali
}

Submitted: 20-04-2020; Revised: 29-09-2020; Accepted: 29-09-2020

\begin{abstract}
Vaginal rejuvenation has become a tradition among Indonesian women. The vaginal rejuvenation tradition was discovered in the Javanese kingdom era through traditional methods using vaginal evaporation and herbs. This tradition extends since the herbal medicine to dry and tighten the vagina, produced by the factory, and distributed to various regions in Indonesia. Traditional vaginal rejuvenation is still in demand and is carried out by Indonesian women to this day. Teenage women to married women consume traditional herbal vaginal seals. Many married women who choose to use a solid concoction "Tongkat Madura", so it is faster to get the results of a dry and tight vagina. As the evolvement of medical technology, recently it is known well a treat to reconstruct the vagina by using laser technology or surgery which is called as vaginal rejuvenation. The woman who does this kind of treatment usually because they want to have an "ideal" vagina for the sake of harmonies sexual relations. The idea of this "dry and tight" vagina comes from generation to generation where every woman in Indonesia is thought to take treat their vagina carefully so that she can satisfy her sex partner. Derive from Foucault's idea of political body technology and some ideas from feminists, this research is aimed to examine the inequity experienced by women in the practice of vaginal rejuvenation in Indonesia. This research is exploratory. The analysis was performed on the data in the form of observations and interviews. This research found inequities experienced by women in the form of objectification of the female body; women's subordination; women suffer in the process of reconstruction of their bodies to fulfill men's pleasures and rules in society.
\end{abstract}

Keywords: Control toward Women; Gender; Patriarchal Constructions; Sexuality; Vaginal Rejuvenation.

*Corresponding author: angelafrenzia@gmail.com

Copyright@ 2020 THE AUTHOR (S). This article is distributed under a Creative Commons Attribution-Share Alike 4.0 International license. Jurnal Kawistara is published by the Graduate School of Universitas Gadjah Mada. 


\begin{abstract}
ABSTRAK
Peremajaan vagina sudah menjadi tradisi di kalangan perempuan Indonesia. Tradisi peremajaan vagina ditemukan pada zaman kerajaan Jawa melalui cara tradisional, yaitu ratus dan jejamuan. Tradisi tersebut meluas sejak jamu untuk mengencangkan dan merapatkan vagina tersebut, diproduksi oleh pabrik dan disebarkan ke pelbagai daerah di Indonesia. Peremajaan vagina tradisional tersebut masih diminati dan dilakukan oleh para perempuan Indonesia hingga kini. Mulai dari perempuan remaja hingga yang telah menikah mengonsumsi jamu tradisional perapat vagina. Banyak pula perempuan menikah yang memilih menggunakan ramuan padat "Tongkat Madura" agar mendapatkan hasil vagina yang kencang dan rapat lebih cepat. Teknologi kedokteran berkembang dan menemukan inovasi yang dikenal dengan istilah rejuvenasi vagina untuk merekonstruksi vagina menggunakan teknologi laser atau bedah operasi. Perempuan melakukan rejuvenasi vagina karena ingin mendapatkan vagina 'ideal' demi keharmonisan hubungan seksual berpasangan. Pentingnya vagina 'kesat dan rapat' bagi perempuan di Indonesia dikarenakan secara turun temurun mereka telah diarahkan untuk selalu merawat vaginanya untuk kepuasan seksual pasangannya. Berangkat dari teori teknologi politis tubuh Foucault serta beberapa gagasan feminis, penelitian ini hendak mengkaji ketidakadilan yang dialami perempuan pada praktik rejuvenasi vagina di Indonesia. Penelitian ini merupakan penelitian eksploratif. Analisis dilakukan terhadap data berupa hasil observasi dan wawancara. Pada penelitian ini ditemukan bentuk-bentuk ketidakadilan yang dialami perempuan, yaitu Perempuan dikontrol untuk mematuhi nilai-nilai berlaku; Tubuh perempuan diobjektivitas; Perempuan disubordinasi; perempuan menanggung penderitaan dalam proses rekonstruksi pada tubuhnya demi memenuhi kesenangan laki-laki dan aturan di masyarakat.
\end{abstract}

Kata kunci: Gender; Konstruksi Patriarki; Kontrol terhadap Perempuan; Rejuvenasi Vagina; Seksualitas.

\section{PENGANTAR}

Di Indonesia, seksualitas hingga kini masih dikaitkan dengan rasa malu. Hal itu dapat ditemukan dengan penggunaan istilah kemaluan untuk alat kelamin manusia. Rasa malu akan seksualitas membentuk anggapan masyarakat Indonesia bahwa perbincangan mengenai seksualitas secara terbuka tidaklah pantas. Pembicaraan seksualitas yang terkesan dibatasi dan diatur ini mempersulit masyarakat Indonesia untuk mendapatkan wawasan mengenai seksualitas serta bagaimana menyikapi wacana tersebut (Bennet, 2018).

Pemahaman seksualitas di Indonesia lebih merujuk pada pembedaan antara perempuan dan laki-laki secara biologis dan sosial hingga psikologis. Pemahaman tersebut menunjukkan gagasan deterministik yang banyak dikritik oleh kaum feminis, tetapi masih digunakan hingga kini. Gagasan Freud tentang Oedipus kompleks dan Penis Envy yang menekankan ketiadaan penis sebagai pemicu perempuan menjadi pribadi yang kurang termotivasi dan narsistik. Gagasan-gagasan tersebut memberi kontribusi terhadap pelemahan perempuan pada banyak aspek kehidupan. Salah satunya dalam aspek sekualitas (Mitchell, 2000). Sebuah penelitian berjudul "Konsep Nasionalisme dan Hak Reproduksi Perempuan: Analisis Gender terhadap Program Keluarga Berencana di Indonesia" oleh Udasmoro (2004), menujukkan bagaimana pelemahan terhadap perempuan dalam aspek seksualitas oleh negara. Melalui konsep nasionalis perempuan dikaitkan sebagai tubuh yang memiliki peran penting bagi negara apabila mengambil bagian menjalankan program pemerintah Keluarga Berencana. Ketimpangan peran gender terjadi ketika implementasinya, Keluarga Berencana tersebut lambat laun menjadi kewajiban yang diperuntukkan kaum perempuan.

Wacana keperawanan dan Female Genital Mutilation merupakan bentuk ketimpangan-ketimpangan seksualitas di Indonesia. Dijelaskan pada artikel BBC (2016), Female Genital Mutilation adalah tindakan menghilangkan bagian permukaan klitoris dengan atau tanpa diikuti pengangkatan sebagian atau seluruh klitoris. Di Indonesia, praktik tersebut ditemukan pada tradisi sunat perempuan suku Bugis. Selain bertujuan melestarikan kelangsungan identitas budaya, 
perempuan Suku Bugis percaya bahwa anak perempuan yang disunat akan kehilangan hasrat seksual pada masa puber sehingga mereka dapat mengontrol perilakunya di hadapan laki-laki (British Broadcasting Coorporation, 2016). Sunat pada perempuan masih dipercaya sebagai upaya untuk memberikan kenikmatan kepada suami mereka kelak, saat melakukan hubungan seksual. Mereka menganggap, dengan memberikan kenikmatan yang lebih kepada laki-laki, perempuan akan lebih dicintai (British Broadcasting Coorporation, 2016).

Selain Female Genital Mutilation Keperawanan terdapat pula wacana keperawanan sebagai bentuk ketimpangan seksualitas. Di Indonesia konsep 'perawan' dikaitkan dengan kondisi vagina yang sempit berselaput dara serta dijadikan tolok ukur moralitas. Perempuan menjadi satu-satunya pihak yang terbebani dan laki-laki diuntungkan karena tidak memiliki tolok ukur moralitas berupa selaput dara. Hal tersebut tampak lestari dengan maraknya upaya tes keperawanan oleh instansi-instansi juga menjadi syarat atlet perempuan dapat mengikuti kejuaran olah raga (CNN Indonesia, 2019).

Ketimpangan serupa ditemukan dalam aturan adat di Indonesia. Adat sesungguhnya kebiasaan yang disesuaikan sistem kepercayaan di masyarakat guna mengatur perilaku manusia, tetapi ketimpangan hadir melalui kesepakatan-kesepakatan bersifat patriarkal yang dibiasakan hingga diakui masyarakat. Tradisi menguji keperawanan perempuan ditemukan pada masyarakat adat Tengger bernama Petekan, dengan cara menekan perut bawah remaja perempuan. Apabila diketahui tidak perawan, maka ditetapkan sanksi (Pujiastuti, 2016). Tradisi serupa ditemukan secara simbolik di suku Tionghoa di Indonesia dengan menempelkan kertas merah di dahi perempuan untuk menentukan nilai mahar (Palung, 2018). Pada Tradisi Ngarot di Indramayu, perempuan dimahkotai bunga lalu diarak keliling desa. Jika bunga layu, dipercaya perempuan tersebut tidak perawan (Syahri, 2015).
Ketiga tradisi adat tersebut menunjukkan ketimpangan antara laki-laki dan perempuan, seolah posisi perempuan adalah komoditas. Laki-laki dianalogikan permintaan dan perempuan adalah pasokannya (Thornham, 2010). Perempuan diposisikan sebagai 'sesuatu' yang memiliki nilai untuk ditukar dengan uang/ mahar dan "keperawanan" merupakan daya jual perempuan.

Tidak hanya remaja yang belum menikah, perempuan menikah juga diarahkan untuk merawat vaginanya selalu 'kesat dan rapat' demi kepuasan seksual pasangannya agar rumah tangga selalu harmonis (Widyantoro, 2010). Vagina 'kesat (kering) dan rapat' dianggap dapat memaksimalkan gesekan saat penetrasi dan dipercaya dapat membuat laki-laki merasakan kenikmatan yang lebih. Untuk itulah, perempuan di Indonesia mengonsumsi jamu tradisional perapat vagina, bahkan beberapa yang telah menikah memasukkan ramuan padat (Tongkat Madura) ke dalam vaginanya (Hull, 2016).

Seiring berkembangnya teknologi kedokteran, ditemukan inovasi peremajaan vagina. Peremajaan vagina dengan teknik kedokteran modern tersebut dikenal dengan istilah vaginal rejuvenation atau rejuvenasi vagina. Rejuvenasi vagina dilakukan untuk memperbaiki labia minora majora, mengencangkan liang senggama, merekonstruksi struktur vulva, bahkan selaput dara menggunakan teknologi laser atau pelvic floor operation (Widyantoro, 2010).

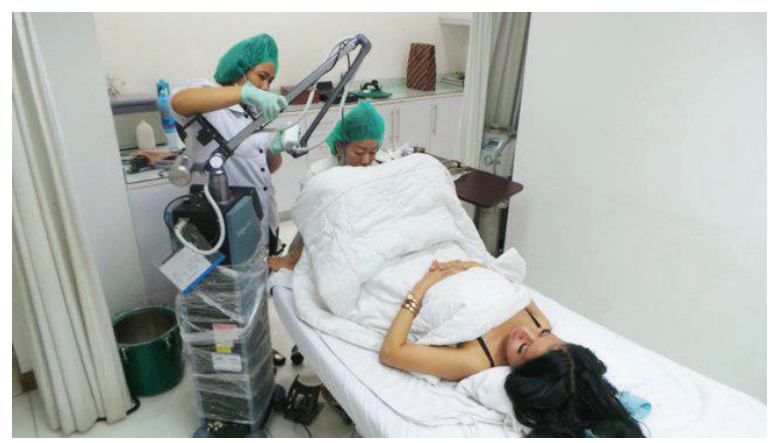

Gambar 1

Foto Rejuvenasi Vagina Menggunakan Teknologi Laser Sumber: Fimela, 2015 
Rejuvenasi vagina sebenarnya sudah dilakukan sejak 2006 di Eropa untuk tujuan kesehatan. Akan tetapi, sejak beberapa tahun belakangan, praktik ini berkembang menjadi tren yang dilakukan para perempuan untuk mempercantik vagina dan mengupayakan vagina kembaliideal.Dr. NiKomang Yeni,SpOG dalam artikel berjudul "Tren Mempercantik Bagian Intim Makin Meningkat", memaparkan data dari American Society of Plastic Surgeons (ASAP) mengenai meningkatnya rejuvenasi vagina secara drastis sejak 2012 hingga 2015. Secara spesifik peningkatan tersebut berawal dari 711 kasus menjadi 6.141 kasus. Data dari BMJ juga menunjukkan bahwa hal serupa terjadi di Inggris, dengan jumlah 580 kasus di tahun 2005 menjadi 2.123 kasus pada tahun 2012 (Nainggolan, 2017). Diperjelas dr. Hardianto SpOG (K), di Indonesia, perempuan yang melakukan rejuvenasi vagina dibagi: kisaran 20 tahun berkeperluan pengembalian selaput dara; $45-50$ berkeperluan pengembalian posisi rahim; dan usia 30-40 tahun dengan tujuan pengencangan (Kompas.com, 2013). Perempuan-perempuan tersebut berkeinginan mendapatkan vagina kencang, kenyal, berwarna terang, lembut, dan berdaya kontraksi kuat (Nainggolan, 2017). Ditambahkan oleh Dr Crouch, British Society for Paediatric and Adolescent Gynaecology, kepada BBC World, para perempuan melakukan rejuvenasi vagina juga disebabkan oleh tekanan emosional dan untuk keharmonisan hubungan seksual berpasangan (Mackenzie, 2017).

Data-data tersebut menunjukkan adanya arahan perempuan agar menjaga kondisi vaginanya untuk kepentingan orang di luar dirinya, sebagaimana dijelaskan oleh Foucault tentang teknologi politis terhadap tubuh bahwa tubuh perempuan dimanipulasi, dilatih, dan dikoreksi oleh sekelompok pemegang kepentingan agar perempuan memiliki kesadaran untuk patuh dan menjalankan aturan-aturan (Foucault, 1997). Berawal dari pemahaman tersebut, penelitian ini terfokus menelusuri bentuk-bentuk ketidakadilan yang dialami perempuan pada praktik rejuvenasi vagina. Jika dalam ranah tradisional tubuh perempuan dikontrol oleh aturan adat hingga mitos-mitos, apakah kontrol terhadap tubuh perempuan juga muncul dalam perkembangan peremajaan vagina modern atau dikenal dengan rejuvenasi vagina? Subjek penelitian ini adalah tiga perempuan berusia antara 30-50 tahun yang memiliki dasar rasional mengenai rejuvenasi vagina dan pernah melakukannya. Pemilihan rentang usia bertujuan agar perspektif subjek dapat diidentifikasi secara jelas terkait bentukbentuk ketidakadilan gender dan seksualitas.

Penelitian ini merupakan penelitian eksploratif di mana dalam pengambilan data, peneliti melakukan analisis terhadap hasil observasi, dan wawancara yang telah dilakukan. Pada penelitian ekspolatif ini, peneliti melakukan observasi dan wawancara mendalam terhadap para responden untuk mendapatkan keberagaaman hasil penelitan. Subjek penelitian ini tidak berdasarkan kategori status perkawinan, latar belakang pendidikan, domisili, atau keikutsertaan dalam organisasi. Akan tetapi, untuk mendapatkan hasil penelitian yang dapat dipetakan secara jelas, subjek penelitian perlu memiliki dasar rasional mengenai rejuvenasi vagina. Subjek penelitian yang dipilih adalah perempuan berusia dewasa tengah (30-40 tahun) hingga dewasa madya (di atas 40 tahun) yang sudah pernah melakukan rejuvenasi vagina. Subjek penelitian juga tidak berprofesi sebagai pekerja seks komersial. Hal ini dikarenakan peneliti hendak merekam pemahaman, pengalaman, dan permasalahan para perempuan yang melakukan rejuvenasi vagina bukan untuk kepentingan komersil.

Pemilihan subjek dilakukan menggunakan undangan terbuka yang disebar melalui pelbagai media sosial, yaitu (Facebook, Instagram, Aplikasi Line, dan Whatsaap). Undangan terbuka dilakukan peneliti melalui postingan di media sosial yang kemudian disebarkan oleh para kolega melalui postingan ulang di media sosial. Peneliti juga menghubungi langsung salah seorang perempuan yang melakukan rejuvenasi vagina dan secara terbuka membagikan pengalamannya melalui artikel blog.

Setelah mendapatkan respon dari calon narasumber, peneliti melakukan observasi dan wawancara informal melalui percakapan 
aplikasi Whatshapp, juga untuk menentukan tanggal wawancara. Ketiga subjek berdomisili di tiga kota yang berbeda, yaitu Jakarta, Bekasi, dan Yogyakarta. Waktu dan tempat pengambilan data pada penelitian ini ditentukan oleh subjek demi kenyamanan subjek dalam memberikan informasi. Penelitian ini bersifat confidential artinya dalam memperlakukan subjek, peneliti akan menjaga kerahasiaan identitas subjek. Peneliti tidak menggunakan nama, melainkan menggunakan istilah narasumber guna menjaga kerahasiaan identitas ketiga subjek. Adapun berikut data singkat dari ketiga narasumber:

Tabel 1 Data Singkat Narasumber

\begin{tabular}{l|l|l}
\hline No. & Narasumber & \multicolumn{1}{c}{ Keterangan } \\
\hline 1. & Narasumber 1 & $\begin{array}{l}\text { Usia di atas 40. } \\
\text { Status: menikah dan } \\
\text { memiliki 3 anak melalui } \\
\text { proses persalinan } \\
\text { normal. Profesi: Tenaga } \\
\text { kesehatan. } \\
\text { Domisili: Bekasi. }\end{array}$ \\
\hline 2. & Narasumber 2 & $\begin{array}{l}\text { Usia 32 tahun. } \\
\text { Status: Belum menikah } \\
\text { namun aktif secara } \\
\text { seksual. } \\
\text { Profesi: Asisten Manager } \\
\text { di sebuah Production } \\
\text { House. } \\
\text { Domisili: Jakarta. }\end{array}$ \\
\hline 3. & Narasumer 3 & $\begin{array}{l}\text { Usia 34 tahun. } \\
\text { Status: Menikah dan } \\
\text { memiliki 2 anak melalui } \\
\text { proses persalinan } \\
\text { normal. } \\
\text { Profesi: Pebisnis online. } \\
\text { Domisili: Yogyakarta, }\end{array}$ \\
\hline
\end{tabular}

Sumber: Data Penelitian, 2018.

\section{PEMBAHASAN}

Rahim, vagina, dan payudara merupakan bagian dari tubuh yang melekat pada diri perempuan. Keberadaan organ-organ biologis maternal pada perempuan seharusnya menjadikan perempuan sebagai individu yang berdaya. Rahim sebagai organ yang mampu menghadirkan kehidupan baru misalnya,
Melekatnya rahim pada perempuan misalnya, menjadikan perempuan sebagai mahkluk yang mampu menghadirkan sebuah kehidupan baru. Seharusnya, dengan begitu perempuan dapat menempatkan dirinya sebagai subjek atau sebagai otonom yang leluasa untuk menentukan bagaimana dan kapan ia akan memiliki anak. Melekatnya organ-organ maternal pada perempuan, dapat memberi keleluasaan pada perempuan dalam menentukan serta membuat keputusan demi kepentingan dan kebaikan dirinya sendiri. Hal tersebut seharusnya dirayakan sebagai keberdayaan bagi perempuan. Penghargaan terhadap pengalaman maternal sebenarnya dapat dilihat pada istilah "Surga berada di bawah telapak kaki ibu". Istilah tersebut hendak mengajak para anak agar dapat menghargai ibunya karena dalam proses persalinan ibu telah bertaruh nyawa (Hernawati, 2016).

Sayangnya, kemelekatan organ-organ maternal pada tubuh perempuan justru menempatkan perempuan tersebut sebagai mahkluk yang tidak berdaya karena nilai-nilai yang diletakkan padanya. Nilai-nilai keibuan yang dilekatkan pada perempuan memang dapat meninggikan perempuan terutama dalam konsep penciptaan kehidupan baru. Akan tetapi, nilai-nilai keibuan tersebut juga membuat perempuan dituntut untuk dapat menyesuaikan diri dengan nilai-nilai keibuan yang telah diberlakukan. Mitchell (2000) bahwa penetapan nilai-nilai konstruktif biologis, telah menyokong perempuan terjerembab pada obsesi untuk menjalankan nilai-nilai tersebut agar merasa utuh, dicintai, dan diperhitungkan oleh lawan jenis.

Berdasarkan pemikiran tersebut, dipahami bahwa konsep tubuh perempuan, secara anatomi telah direduksi menjadi tubuh yang melakukan peran reproduksi dan sebagai objek laki-laki. Keberadaan organ-organ maternal pada tubuhnya, tidak sepenuhnya menjadikan perempuan sebagai subjek yang aktif dan memiliki kebebasan untuk berekspresi. Gagasan tersebut membantu untuk memahami bahwa dalam bangunan patriarki, tubuh perempuan telah diikatkan erat-erat sebagai tubuh maternal. Ikatan tersebut lalu 
mengarahkan perempuan untuk menjalani nilai-nilai keibuan yang telah dibangun. Alhasil melekatnya organ-organ maternal pada tubuh perempuan justru menempatkannya sebagai mahkluk yang tunduk pada nilai-nilai keibuan sehingga perempuan tidak memiliki otoritas secara penuh terhadap tubuhnya sendiri.

Sebuah gagasan Mitchell (2000) menjelaskan perihal asal mula ketimpangan tersebut. Ini berawal dari konsep bernama psikoseksual deterministik yang digugah oleh Freud. Konsep psikoseksual deterministik menggagas bahwa penis pada anatomi tubuh laki-laki menjadikannya utuh. Perempuan dianggap sebagai individu tidak lengkap karena tidak berpenis. Konsep pembedaan berdasarkan anatomi tubuh tersebut memusatkan perempuan untuk menutupi kekurangan pada dirinya bahkan disebutkan bahwa reproduksi (memiliki bayi) merupakan upaya perempuan untuk menjadi utuh.

Menyoal penetapan nilai-nilai konstruktif berdasarkan biologis, di Indonesia terdapat sebuah konsep 'ibu sejati'. Dalam konsep tersebut tubuh perempuan adalah tubuh reproduktif yang harus menjalankan fungsi reproduksi. Lebih jauh, konsep 'ibu sejati' menginginkan perempuan untuk berkorban lebih demi mendapatkan gelar tidak tertulis tersebut. Oleh karena itu, pilihan proses persalinan melalui vagina (pervaginam) dijadikan tolok ukur kesejatian. Masyarakat menganggap bahwa proses pervaginam membutuhkan pengorbanan lebih besar karena lebih menyakitkan ketimbang proses operasi caesar. Mitos ini dibumbui pula dengan anggapan bahwa melahirkan pervaginam lebih membangun kedekatan batiniah ibu dan bayi. Terhadap konsep ini, banyak perempuan yang tidak menjalani proses persalinan pervaginam mendapatkan diskriminasi bahkan oleh sesama perempuan (Wargadiredja, 2017).

Indikasi obsesi pemenuhan konsep 'ibu sejati' ditemukan pada narasumber, melalui kutipan berikut ini:

Anakku tiga, ketika aku menikah aku sudah bertekad ya, ingin total menjadi ibu. Aku hamil, melahirkan normal, menyusui anak-anakku selama dua tahun. Aku tidak mengurus tubuhku saat itu, saat aku mendedikasikannya untuk anak-anakku. Setelah anakku yang paling kecil sudah bertumbuh, aku merasa cukup, aku tidak akan hamil lagi. Kemudian, aku berpikir bagaimana aku mengurusi tubuhku karena sudah selesai menurut aku, tugasku sebagai seorang ibu. Di situ aku mulai berpikir bagaimana untuk meremajakan kembali organ vital dan payudaraku. (Wawancara Narasumber 1, 16 Juni 2018: 4-13).

Oke, ini saya kan ibu dengan dua anak. Kedua anak saya, semua persalinan normal. Ya, biar merasakan jadi wanita seutuhnya. (Wawancara Narasumber 3, 9 September 2018: 17-19).

Berdasarkan kedua kutipan tersebut ditemukan ada keinginan yang besar pada perempuan untuk merasakan proses persalinan pervaginam. Pemenuhan nilai-nilai keibuan tersebut bahkan dianggap sebagai pencapaian terbesar perempuan. Mitos 'ibu sejati' tersebut berkembang di masyarakat dibantu sesama perempuan seperti: ibu atau nenek. Hal tersebut menegaskan gagasan Foucault (1977) mengenai pematuhan tubuh yang dilakukan menggunakan mitos-mitos yang dikembangkan oleh masyarakat.

Lebih jauh, gagasan Foucault mengenai bio power dan kaitannya dengan kontrol terhadap reproduksi perempuan ditemukan pada teknologi kedokteran modern. Penemuan bayi tabung dan alat kontrasepsi adalah contoh jelas rezim modern bio politic menempatkan power, knowledge, dan perangkat aturan pada tubuh individu dan sosial sebagai metafora kolektif (Udasmoro, 2004).

Apabila memahami gagasan Foucault, dipahami bahwa mitos menjadi 'ibu sejati' dikembangkan masyarakat untuk mengarahkan perempuan sebagai individu yang sudah sewajarnya menjalankan ekspektasi masyarakat sebagai tubuh biologis maternal yang mampu menjalani proses-proses keibuan secara penuh termasuk salah satunya adalah melakukan persalinan pervaginam.

Penggambaran konsep 'ibu sejati' masyarakat Indonesia, secara jelas dapat dilihat melaluijurnalberjudul "ReproduksiWomanhood 
Dalam Novel Bunda: Kisah Cinta Dua Kodi Karya Asma Nadia." Pada penelitian tersebut, konstruksi mengenai 'ibu sejati' di Indonesia terepresentasikan ketika penulis novel tersebut mendeskripsikan peran perempuan sebagai ibu. Pada konteks ketubuhan, perempuan sebagai ibu, bertanggung jawab penuh untuk menghasilkan keturunan yang sempurna. Sebagai pilar keluarga, perempuan sebagai ibu juga bertanggung jawab penuh untuk mengutamakan kepentingan bahkan berkorban demi anak-anak mereka (Udasworo, 2017).

Sebagaimana pemaparan 'ibu sejati' Foucault dan Udasmoro, dedikasi perempuan dalam menjalankan nilai-nilai keibuan tampak pada kutipan Narasumber pertama (2018), "Setelah anakku yang paling kecil sudah bertumbuh, aku merasa cukup, aku tidak akan hamil lagi. Kemudian, aku berpikir bagaimana aku mengurusi tubuh aku." Dalam kutipan tersebut perempuan menempatkan tubuhnya sebagai 'tubuh keibuan' di atas kebutuhan dan kesenangan dirinya. Pada kutipan narasumber pertama (2018) selanjutnya, “...karena, sudah selesai menurut aku, tugasku sebagai seorang ibu. Di situ aku mulai berpikir bagaimana untuk meremajakan kembali organ vital dan payudaraku", memperjelas bahwa peremajaan vagina menjadi pilihan bagi para perempuan yang mengalami penurunan fungsi organ vaginanya sebab memprioritaskan nilai-nilai keibuan.

Temuan di atas, menekankan kembali pemaparan Udasmoro (2017) bahwa ibu sejati harus mengutamakan kepentingan anakanak mereka, dengan begitu mereka dapat disebut sebagai pilar keluarga. Pada kutipan narasumber pertama, perempuan-perempuan tersebut telah mendahulukan tubuhnya untuk menjalankan fungsi sebagai tubuh maternal barulah setelahnya mereka memikirkan kepentingan tubuh sebagai tubuh seksual dengan melakukan rejuvenasi vagina. Atas konstruksi patriarkal tersebut, keberadaan organ-organ maternal pada tubuhnya tidak menjadikan perempuan sebagai subjek yang aktif dan memiliki kebebasan untuk berekspresi.
Alih-alih membebaskan, nilai-nilai keibuan justru mengontrol tubuh perempuan. Ini tampak menegaskan kembali gagasan Foucault bahwa individu dikontrol untuk mengesampingkan kepentingannya dan menjalankan ekspektasi masyarakat hingga pada bagian terintim dengan menggunakan norma-norma (Foucault, 1997). Hal ini Foucault memang tidak menyebutkan bahwa kontrol diarahkan khusus kepada perempuan. Akan tetapi, gagasan tersebut cukup sesuai apabila digunakan untuk memahami bentuk kontrol terhadap perempuan dalam rejuvenasi vagina.

Konsep ibu sejati tak jarang menjadikan sesama perempuan berkompetisi untuk saling menunjukkan bahwa mereka mampu memenuhi kriteria-kriteria tersebut. Bahkan, seringkali perempuan melakukan subordinasi terhadap perempuan lain yang memiliki pandangan berbeda atau tidak memenuhi standar ibu sejati. Hal tersebut ditemukan pada banyaknya stigma-stigma yang diberikan kepada perempuan yang melahirkan caesar. Para perempuan yang menjalani proses melahirkan caesar disubordinasi dan dimarginalisasi oleh sesama perempuan dan masyarakat. Mereka dilabeli sebagai penakut, pemalas, dan tidak berjiiwa keibuan (Wargadiredja, 2017) dan (Rohmaitun, 2017).

Apabila memahami gagasan-gagasan tersebut, dipahami bahwa konsep 'ibu sejati' telah dirumuskan oleh masyarakat patriarkal berdasarkan kemampuan maternal perempuan. Atas rumusan tersebut perempuan ditata dan dikontrol untuk dapat melakukan tugas maternal-nya, yaitu mengandung, melahirkan, dan hingga merawat. Perempuan lalu mengesampingkan kepentingan tubuh dan seksualitasnya demi menjalankan tanggung jawabnya terhadap keluarga dan masyarakat. Ini menyebabkan perempuan menjadi individu yang tidak dapat mandiri menilai kebutuhan tubuhnya bahkan terikat dengan penilaian masyarakat untuk proses yang dialami oleh tubuhnya sendiri seperti persalinan, menyusui, dan hingga perawatan vagina.

Sistem patriarkal telah melakukan pengelolaan terhadap tubuh perempuan dengan membangun mitos-mitos kecantikan 
yang menyasar organ reproduksi, bentuk tubuh, rambut, dan hingga wajah. Kini mitosmitos tersebut masih lestari, meskipun konsep "cantik" berevolusi sesuai dengan budaya yang ada. Hal itu diperkuat oleh pemaparan bahwa mitos kecantikan dihadapi oleh semua perempuan dari pelbagai ras dan budaya. Standar perempuan cantik seperti bertubuh langsing, berkulit cerah, dan berwajah simetris tanpa cacat telah mengakar kuat selama beberapa dekade (Naomi, 2002).

Lebih jauh Naomi (2002) memaparkan bahwa terhadap standar-standar kecantikan perempuan kerap menjadi terobsesi untuk memiliki citra diri yang serupa atau mendekati standar kecantikan tersebut. Upaya itu ternyata juga dialami oleh seorang narasumber ada pernyataan berikut ini,

"Saya dari dulu senam kegel, fitness, yoga untuk menjaga bentuk tubuh saya karena ya penting juga menjaga bentuk tubuh. Bukan karena suami yang suruh". (Wawancara Narasumber 3, 9 September 2018: 139-142).

Pada kutipan tersebut, narasumber menekankan bahwa menjaga bentukideal tubuh adalah tanggung jawab individu perempuan tanpa diperintah atau diarahkan orang lain. Memang, jika dilihat sekilas melalui kutipan tersebut, tampaknya standar kecantikan yang menyasar perempuan memang tidak tampak sebagai sebuah pengaturan terhadap tubuh perempuan. Hal itu tampaknya disebabkan tidak ada hukum atau aturan yang menyatakan secara jelas bahwa perempuan harus memiliki konsep cantik yang telah dibangun.

Naomi (2000) memaparkan bahwa standar-standar kecantikan telah dinaturalisasi oleh media dengan cara menampilkannya pada majalah dewasa dan fesyen. Media-media memajang gambar-gambar perempuan dengan tubuh langsing, berkulit putih, dan wajah tanpa cela yang diberi label cantik dan tak jarang dianggap sebagai dambaan para lelaki.

Pemaparan tersebut dapat dipinjam untuk melihat bagaimana sebenarnya patriarkal mengatur tubuh perempuan. Memang aturan mengenai bentuk tubuh perempuan tersebut tidak menyentuh tubuh secara langsung atau melalui aturan-aturan tertulis. Akan tetapi, tubuh perempuan dibentuk melalui standarstandar kecantikan yang dibangun dan terus direproduksi di pelbagai media dengan cara memajang gambar-gambar perempuan yang dilabeli 'ideal' oleh masyarakat patriarkal. Lalu, atas standar-standar yang dinaturalisasi tersebut perempuan mengalami ketidakpuasan terhadap tubuhnya hingga bersedia mengambil risiko untuk mengubah bentuk tubuh, wajah, kulit, dan hingga vagina agar serupa dengan standar yang telah dibangun. Hal ini menunjukkan betapa kuatnya bangunan patriarkal dalam masyarakat Indonesia hingga mampu mempengaruhi pola pikir perempuan.

Di Indonesia, perempuan tidak hanya dihadapkan pada standar yang berkaitan dengan tubuh dan wajah saja. Perempuan Indonesia juga dihadapkan pada standar ideal berupa 'keperawanan'. Wacana keperawanan di Indonesia adalah bukti sistem patriarkal tidak menyisakan apapun pada tubuh perempuan untuk kepentingan perempuan sendiri. Bagian terintim dari perempuan yaitu vagina, diatur untuk patuh melalui konsep keperawanan. Untuk itu, masyarakat Indonesia, vagina berselaput dara dijadikan standar ideal untuk perempuan yang belum menikah. Di Indonesia, 'keperawanan' menjadi sebuah mitos yang keberadaannya sudah mengakar kuat sejak tradisi adat istiadat terlibat bersamanya. Mitos tersebut bahkan dijustifikasi ke dalam aturan agama sehingga keberadaanya tetap lestari hingga era modernisasi.

Pentingnya keperawanan bagi perempuan yang belum menikah di Indonesia, dapat dijumpai pada beragam tradisi di antaranya tradisi ngarot, kertas merah, dan peteken yeng telah dijelaskan sebelumnya. Tradisitradisi tersebut mengontrol perempuan agar menjaga perilaku seksual mereka apabila ingin dianggap "cantik" (bermoral=berselaput dar). Menjadikan vagina berselaput dara sebagai standar moral merupakan strategi masyarakat patriarkal agar perempuan patuh untuk mengelola tubuh dan hasrat seksualnya sebelum menikah.

Terhadap standar tersebut, mereka yang kehilangan selaput dara kerena 
pemaksaan seksualitas, pemerkosaan, dan hingga insiden tertentu lebih memilih untuk menyembunyikannya. Beberapa di antaranya bahkan berupaya menutupi dengan melakukan rekonstruksi selaput dara atau hymenoplasty seperti yang dijelaskan pada kutipan berikut ini:

Nah, gini, ada banyak respon dari blog gue. (blog tentang rejuvenasi vagina) Mereka cerita, kalau mereka pernah dipaksa ML terus ditinggal pacarnya. Terus dia mau nikah sama yang lain, tapi karena nggak virgin lagi mau operasi (hymenoplasty), karena takut calon suami kecewa. (Wawancara Narasumber 1, 16 Juni 2018: 200-203).

Kutipan tersebut merupakan sepenggal cerita tentang wacana keperawanan yang terjadi di Indonesia, di mana vagina berselaput dara merupakan wujud kepatuhan kepada calon suami dan ukuran moralitas perempuan. Terhadap standar ideal moral tersebut, perempuan yang kehilangan selaput dara sebelum menikah seolah merasa perlu untuk melakukan rejuvenasi vagina berupa hymenoplasty untuk memenuhi standar yang telah dibangun. Perihal tersebut dapat dilihat pada pengambaran Foucault mengenai histerisasi tubuh perempuan, di mana tubuh perempuan tidak dapat dipisahkan dari tanggung jawab biologis-moral. Perempuan adalah tubuh penuh seksualitas; perempuan tubuh medis yang dimasukkan patologi intrinsik; dan perempuan adalah tubuh yang dihubungkan secara organis dengan masyarakat (Foucault, 2000). Dalam hal ini, perempuan merasa hymenoplasty dilakukan karena keperawanan dianggap sebagai tanggung jawab perempuan dalam menjamin kesenangan seksual pasangannya kelak dan untuk memenuhi standar moral yang ada di masyarakat. Hal tersebut cukup menjelaskan perihal tubuh perempuan dikaitkan dengan tubuh sosial sehingga perempuan dibebani tanggung jawab besar pada tubuhnya.

Mitos tersebut direproduksi terusmenerus hingga dipahami oleh perempuan sebagai sesuatu yang tidak mengekang melainkan diciptakan memang untuk kebaikan kaumnya. Pada akhirnya perempuan yang kehilangan keperawanannya (bahkan disebabkan pemaksaan seksual dan insiden), kemudian mendapatkan label tak bermoral dan stigma sebagai perempuan murahan, nakal, binal, dan sejenisnya. Alhasil perempuan kemudian mensubordinasi dirinya sendiri atas ketidakmampuannya menjalani standarstandar tersebut. Atas operasi tersebutlah perempuan memilih rejuvenasi vagina berupa hymenoplasty untuk memenuhi standar masyarakat dan demi merealisasikan kebutuhan seksualitas laki-laki berbalut moralitas. Perempuan diatur perilakunya, tubuhnya hingga lebih jauh vaginanya bukan untuk kenikmatan atau kepentingan dirinya sendiri melainkan untuk kepentingan masyarakat patriarkal.

Tidak dapat dipungkiri bahwa langgengnya mitos keperawanan di masyarakat Indonesia, disokong oleh tradisi adat, agama, dan turut pula dikomersilkan oleh industri-industri kecantikan guna mengeruk keuntungan. Industri-industri tersebut menyasar para perempuan yang telah menikah. Narasi yang digaungkan bahwa perempuan yang sudah menikah dan melahirkan dapat pula memiliki vagina yang perawan. Konsep keperawanan menjadi bahan dagangan. Keperawanan bak sebuah produk yang dikemas dalam bahasa marketing untuk menarik pembeli, yaitu para perempuan.

Seharusnya, perkembangan teknologi komunikasi dapat digunakan untuk menyadarkan masyarakat mengenai kesetaraan gender dalam seksualitas. Sayangnya pelanggengan mitos keperawanan ditemukan melalui reproduksi media mengenai pentingnya keperawanan bahkan bagi mereka yang sudah menikah. Gagasan tersebut menghendaki perempuan yang telah menikah tetap perlu menjaga vagina mereka agar tetap terasa seperti perawan, demi membahagiakan pasangan (Taylor, 2017). Hal tersebut dapat dipahami melalui kutipan salah seorang narasumber ini,

\footnotetext{
"(hymenoplasty).......ya bikin moment juga sih. Dia nggak minta ngga masalah memang, cuma gue pingin biar suami juga ngerasain sensasi malam pertama lagi gitu. Sebenernya suami nggak ada masalah sih,
} 
cuma ya pingin aja." (Wawancara Informan 1, 16 Juni 2018: 81-88).

Kutipan tersebut memperjelas bahwa wacana keperawanan direproduksi terusmenerus agar perempuan patuh untuk merawat keremajaan vaginanya, sebagai bentuk tanggung jawab dalam rangka membahagiakan pasangannya. Sebagai perempuan yang telah menikah bertahun-tahun, narasumber tetap merasa perlu melakukan hymenoplasty demi memberi sensasi malam pertama kepada suaminya.

Sebuah gagasan memaparkan bahwa kebutuhan individu untuk melakukan design ulang demi peningkatan fungsi dan tampilan tubuh tidak lepas dari perkembangan teknologi dan bersama dengan asumsi budaya tentang apa yang dianggap "tidak normal," "normal," atau "ditingkatkan". Penilaian tersebut dapat berbeda antara masyarakat, tradisi, dan dari waktu ke waktu (Hogle, 2016). Menggunakan gagasan tersebut dapat dipahami bahwa design ulang untuk peningkatan fungsi dan tampilan vagina, dapat dimungkinkan karena adanya standar vagina 'ideal' yang dibentuk oleh masyarakat. Standar tersebut direproduksi dunia medis dengan membuat konsep vagina yang "normal" dan "tidak normal". Vagina yang "tidak normal" ini, kemudian oleh dunia kedokteran perlu untuk "ditingkatkan" menggunakan rejuvenasi vagina. Justifikasi tersebut dibantu oleh media hingga konsep tersebut dianggap sebagai kebenaran.

Kondisi lain yang mendukung temuan tersebut adalah pandangan dari tentang biopower, di mana hubungan bentuk kekuasaan modern beroperasi melalui disiplin tubuh dan modifikasi. Tubuh dikuasai dan dikontrol sedemikian rupa dan mengalami perubahan bentuk kekuasaan sehingga tidak lagi diperlukan tindakan yang langsung menyentuh tubuh, untuk secara efektif mengendalikan individu (Foucault, 1997).

Perempuan seharusnya memiliki hak terhadap kebebasan seksualnya sama seperti laki-laki dapat secara bebas mengekspresikan seksualitasnya (MacKinnon, 1989). Akan tetapi, fenomena rejuvenasi vagina ditemukan ketidakadilan gender dalam seksualitas.
Kontrol terhadap perempuan melalui mitos keperawanan, hendak menegaskan bahwa dalam seksualitas perempuan tidak memiliki kesempatan yang sama besarnya dengan laki-laki. Ketidakadilan tergambarkan ketika standar tersebut menjadikan perempuan tidak dapat secara bebas mengeksplorasi seksualitasnya (seperti masturbasi), sebagaimana laki-laki dapat melakukan masturbasi (onani) tanpa harus dibayangi ketakutan akan kehilangan selaput dara. Standar vagina ideal telah menempatkan posisi perempuan (vaginanya), sebagai sebuah objek yang keberadaannya diatur dan ditata sesuai dengan bangunan masyarakat patriarki, untuk kepentingan laki-laki. Inilah yang menjadikan perilaku praktik rejuvenasi vagina dilakoni oleh banyak perempuan Indonesia. Hal tersebut dapat dibuktikan melalui penuturan narasumber perihal respon yang didapatnya dari ulasannya mengenai vaginoplasty,

"Ada juga beberapa yang mau operasi karena suaminya selingkuh dan ingin menarik suaminya kembali" (Wawancara Informan 1, 16 Juni 2018: 213-215).

Pemaparan pada kutipan tersebut membuktikan bahwa perempuan melakukan rejuvenasi vagina karena adanya arahan untuk tampil ideal demi menarik perhatian lawanjenis (Thornham, 2010). Ini karena rejuvenasi vagina dijadikan oleh beberapa perempuan sebagai jalan keluar mendapatkan kembali pasangan yang meninggalkan mereka. Dalam relasi pernikahan, perempuan kerap diposisikan sebagai pihak yang bertanggung jawab menjaga keharmonisan. Rejuvenasi vagina nyatanya menunjukkan adanya ketimpangan karena tubuh dan seksualitas istri dikelola dan diarahkan bukan untuk kepentingan dirinya melainkan untuk kesenangan pasangan dan kestabilan rumah tangga. Hal ini juga mempertegas pandangan bahwa seksualitas merupakan strategi kekuasaan untuk mengontrol aktivitas tubuh individu untuk mencapai tujuan tertentu (Foucault, 1997).

Pada temuan tersebut, suami menjadi superior karena sangat diinginkan oleh istrinya, sekalipun telah melakukan perselingkuhan. 
Di pihak lain, ada perempuan yang merasa telah mengalahkan perempuan lainnya karena berhasil membuat seorang suami meninggalkan perempuan lain dan memilih bersamanya. Ini seakan membenarkan pandangan bahwa standar-standar yang diciptakan patriarkal mampu menciptakan persaingan antar perempuan karena obsesi terhadap standarstandar tertentu (Naomi, 2002).

Mungkin perempuan tampak berdaya ketika melakukan rejuvenasi vagina. Akan tetapi, temuan tersebut ada kontestasi yang nyata antara dua perempuan untuk memperebutkan pengakuan dan cinta dari seorang laki-laki. Rejuvenasi vagina dalam hal tersebut menjadi bentuk ketidakberdayaan seorang perempuan manakala itu dilakukan untuk mendapatkan kembali suami yang tidak loyal kembali ke pangkuannya. Sekilas tampak bahwa perempuan memiliki pilihan untuk melakukan rejuvenasi vagina dan mampu memperbaiki kualitas hubungan seksual suai-istri, tetapi pada akhirnya rejuvenasi vagina tersebut menegaskan bahwa untuk mendapatkan kembali sebuah relasi berpasangan yang harmonis, perempuanlah yang harus berkoban melakukan segala upaya untuk menyenangkan pasangannya. Rejuvenasi vagina adalah salah satunya.

Temuan tersebut mengingatkan pada sebuah penjabaran MacKinnon (1998) bahwa dalam seksualitas, laki-laki menciptakan keinginan seksualnya untuk kemudian dilayani dan dipenuhi oleh perempuan. Melalui rejuvenasi vagina, perempuan ternyata telah menyediakan dirinya untuk memenuhi standar-standar yang diciptakan patriarkal.

Pada budaya patriarkal, tak dapat dipungkiri bahwa tubuh perempuan memiliki kedudukan sebagai objek penderita. Tradisi di belahan dunia di pelbagai era, menempatkan tubuh perempuan sebagai tubuh yang yang ditempa oleh konsep-konsep kecantikan. Pada era Victoria perempuan rela menggunakan korset super ketat dengan ikatan khusus di bagian pinggang demi menarik perhatian lawan jenis (Gamble, 2010). Ditambahkan oleh Gamble (2010) pada tahun 80an puluhan ribu perempuan di Eropa yang menyiksa diri dengan melakukan pengurangan porsi makan demi membentuk tubuh serupa para model pada majalah fesyen. Pada peradaban China tepatnya dinasti Song (960-1297 Masehi), para perempuan menggunakan sepatu berukuran kaki balita disebut Lotus untuk membentuk kaki mereka. Rasa sakit dialami perempuan ketika jari-jari kaki mereka ditekuk dan diikat hingga mengalami perubahan struktur. Hal itu dilakukan demi terbentuk kaki yang kecil dambaan para lelaki (National Geographic Indonesia, 2018).

Di Indonesia, design ulang tubuh yang menyakitkan perempuan juga banyak ditemui. Tradisi Kerik Gigi perempuan suku Mentawai, misalnya. Tanpa dibius, gigi perempuan diukir menyerupai segitiga menggunakan alat yang terbuat dari besi tajam dengan tujuan mendatangkan kebahagiaan bagi pasangan mereka kelak (Kumparan, 2018). Di Papua, Suku Dani memiliki Tradisi Iki Palek yang mengharuskan perempuan-perempuan tua mengalami memotong jari apabila ada anggota keluarga yang meninggal sebagai simbol kesetiaan dan kedukaan para perempuan (Alicia, 2018).

Mulai dari korset hingga pemotongan jari menjadi bukti bahwa meski dengan bentuk dan cara yang berbeda, tubuh perempuan menjalani pendisipinan dan mengalami penderitaan/rasa sakit akibat ditata, ditempa, dan diubah. Perempuan dipatuhkan untuk melakukan pengubahan sebagai bukti kesetiaan kepada pasangan dan masyarakat adat. Oleh masyarakat patriarkal, standarstandar disisipkan unsur romantis seperti 'simbol kesetiaan' dan 'simbol kebahagiaan'. Romantisasi serupa tampak pada peremajaan vagina tradisional maupun rejuvenasi vagina modern. Pada peremajaan vagina tradisional, perempuan dilatih menahan rasa pahit jejamuan perapat vagina demi mempersembahkan malam pertama yang tak terlupakan bagi suami. Mulai dari penggunan korset, pemotongan jari, dan peremajaan vagina merupakan bukti bahwa dengan bentuk dan cara yang berbeda, tubuh perempuan dilatih mengalami rasa sakit untuk menjalani konstruksi di masyarakat. 
Menurut Widyantoro et al (2010) peremajaan vagina tradisional dapat menimbulkan risiko berupa infeksi vagina. Tidak hanya itu, jamu-jamuan yang dikonsumsi dalam jangka waktu panjang dapat menyebabkan kerusakan pada sistem kesehatan reproduksi perempuan. Jamujamuan dibuat untuk mengondisikan agar liang vagina menjadi kering. Vagina yang kering dapat mengganggu kelembaban alaminya sehingga menimbulkan pelbagai masalah seperti bakteri dan jamur. Rasa sakit akan bertambah apabila vagina yang kering mengalami gesekan saat melakukan hubungan seksual. Alhasil perempuan akan lebih mudah terinfeksi penyakit menular seksual.

Berdasarkan penjelasan tersebut dipahami bahwa peremajaan vagina tradisional menyebabkan penderitaan perempuan yang sifatnya akumulatif. Hal tersebut tak jauh berbeda dengan rejuvenasi vagina modern. Pada rejuvenasi teknik operasi bedah seperti vaginoplasty, labiaplasty dan hymenoplasty misalnya, juga menimbulkan rasa sakit. Namun, yang membedakan dengan rejuvenasi vagina tradisional adalah rasa sakit atau penderitaan dialami perempuan sesaat setelah perempuan tindakan tersebut. Perempuan tetap mengalami efek samping setelah menjalani operasi seperti dipaparkan pada kutipan ini,

Masuk ruang operasi sekitar jam 5 sore, aku dengar adzan magrib itu udah di ruangan aku. Jam 10 malam, itu biusnya mulai hilang, itu rasanya kayak mules banget. Kayak orang mau partus, mau melahirkan, dan aku masih pake kateter, dan sebenarnya 1×24 jam post operasi aku ga boleh turun dari tempat tidur. Tapi, karena mules, kayak mau melahirkan mau pup, itu ya gue turun ke toilet donk gue, rasanya sempoyongan. Akhirnya ke toilet, tapi nggak keluar, terus suster bilang nggak boleh (berjalan/ ke kamar mandi)......... ternyata itu emang kayak gitu karena efek obatnya. Even elo mules banget ga bakal buang air besar." (Wawancara Informan 1, 16 Juni 2018: 50-59).

"Malamnya abis operasi ya agak mules sih perutnya, katanya efek obat, mbak. Tapi ya, saya dikasih kayak obat tidur, dibawa tidur jadi nggak berasa. Besoknya itu agak, nyeri vagina saya". (Wawancara Informan 3, 9 September 2018: 76-79). “....Udah seminggu kan, nyerinya udah ilang, udah nggak ada bercak darah lagi". (Wawancara Informan 3, 9 September 2018: 97-98).

Pada kutipan pernyataan-pernyataan tersebut, hal yang perlu ditelisik adalah perihal penerimaan perempuan terhadap pelbagai rasa sakit. Pasca melakukan rejuvenasi vagina, perempuan harus rela bersahabat dengan rasa sakit pada vaginanya dan tubuh lainnya. Demi memiliki vagina dengan kondisi seperti perawan, perempuan harus mengalami penderitaan pada tubuhnya yang cukup beragam. Rasa nyeri pada luka jahitan, mulas pasca operasi, pendarahan pada bekas jahitan, kesulitan buang air kecil selama penyembuhan, dan pelbagai ketidaknyamaan lain yang harus dialami oleh tubuh perempuan dalam waktu yang cukup lama.

Pada kutipan-kutipan tersebut perlu ditelisik perihal penerimaan perempuan terhadap pelbagai rasa sakit dan ketidaknyamanan yang mereka dialami pasca-vaginoplasty. Berdasarkan kutipankutipan tersebut dipahami bahwa segala rasa sakit dan ketidaknyamanan tersebut dianggap oleh perempuan sebagai bagian dari proses alamiah yang harus dijalan sebagai perjuangan untuk sebuah pencapaian, dalam hal ini vagina yang kembali seperti perawan. Rejuvenasi vagina tampak memberi kebebasan perempuan untuk memutuskan apa yang akan dilakukan pada tubuhnya. Akan tetapi, jika diperhatikan, perempuan tetaplah yang mengalami serangkaian rasa sakit akibat melakukan pengubahan pada tubuhnya demi mendapatkan vagina 'ideal'.

\section{SIMPULAN}

Fenomena peremajaan vagina sesungguhnya telah menjadi tradisi di Indonesia. Akan tetapi, peremajaan vagina tersebut berkembang bersamaan dengan berkembangnya teknologi modern di dunia kesehatan. Para perempuan kemudian melihat peremajaan vagina menggunakan teknologi modern atau disebut dengan rejuvenasi vagina, sebagai pilihan baru. Mulanya 
rejuvenasi vagina hanya diperuntukkan kepada perempuan yang mengalami gangguan kesehatan kandung kemih dan saluran uretra lalu berkembang menjadi upaya perempuan untuk mendapatkan vagina yang ideal.

Hal ini dapat dilihat melalui perjalanan perubahan peremajaan vagina dari tradisional hingga modern yang dikenal dengan istilah rejuvenasi vagina. Perempuan Nusantara terutama Jawa, memiliki kedekatan dengan jamu tradisional sebagai upaya perawatan vagina guna peremajaan. Mereka percaya bahwa vagina yang kesat dan sempit akan menciptakan sensasi kenikmatan luar biasa kepada pasangan saat melakukan penetrasi. Kepercayaan tersebutlah yang membentuk pendisiplinan terhadap perempuan untuk mengondisikan vaginanya kesat dan rapat dengan mengonsumsi jamu perapat vagina sejak remaja. Pada tradisi minum jamu tersebut, ditemukan bahwa vagina yang kesat dan sempit menjadi konsep ideal yang ditetapkan oleh masyarakat partiarkal untuk dilakoni oleh para perempuan. Oleh karena itu, tradisi tersebut dapat pahami sebagai manifestasi kontrol terhadap bentuk tubuh (dalam hal ini vagina) dan seksualitas perempuan. Pada akhirnya peremajaan vagina cara tradisional tersebut diterima perempuan sebagai upaya untuk menjalani tugasnya sebagai tubuh yang patuh terhadap masyarakat patriarkal.

Perkembangan peradaban memberikan kontribusi besar terhadap perubahan praktik peremajaan vagina. Rejuvenasi vagina merupakan bentuk perkembangan upaya perawatan vagina guna peremajaan tersebut. Sayangnya, ketidakadilan masih ditemukan pada praktik rejuvenasi vagina (peremajaan vagina yang menggunakan teknologi modern kedokteran). Pada mitos ibu sejati, perempuan dikendalikan agar menjalankan perannya sebagai tubuh keibuan yang harus melakukan persalinan melalui vagina (pervaginam). Akibatnya, perempuan tidak memiliki kendali untuk menilai tubuhnya sendiri karena terikat dengan penilaian masyarakat bahkan untuk proses yang dialami oleh tubuhnya sendiri.

Kendali terhadap tubuh perempuan juga dilakukan menggunakan standar-standar kecantikan. Terhadap bangunan kecantikan tersebut, perempuan mengalami ketidakpuasan akan tubuhnya dan pada akhirnya bersedia mengambil risiko untuk mengubah tubuhnya agar serupa dengan standar tersebut. Salah satunya dapat dilihat pada upaya hymenoplasty yang ingin dilakukan oleh perempuan untuk memenuhi standar-standar keperawanan yang ditetapkan oleh masyarakat patriarkal. Penderitaan perempuan tidak sebatas itu saja. Pada beragam upaya memenuhi standarstandar yang ditetapkan oleh patriarkal, tubuh perempuan harus menerima pelbagai kesakitan. Pada akhirnya penelitian ini menyimpulkan bahwa melalui rejuvenasi vagina, tubuh, dan seksualitas perempuan masih dikontrol, diatur, dan dipatuhkan menggunakan nilai-nilai, standar-standar ideal hingga mitos-mitos yang dibangun oleh patriarkal. Tubuh, perilaku hingga seksualitas perempuan dibatasi, dikelola, diarahkan, dan bahan mengalami penderitaan untuk memenuhi ekspekstasi masyarakat patriarkal.

\section{DAFTAR PUSTAKA}

Alicia, N. (2018, September 28). Iki Palek Tradisi Potong Jari Sebagai Tanda Kehilangan dan Kesetiaan. (G. L. Widyaningrum, Penyunt.)

Bennet, L. R. (2018). Seksualitas di Indonesia: Politik Seksual, Kesehatan, Keragaman dan Representasi . (N. d. Nurmila, Penerj.) Jakarta: Yayasan Pustaka Obor Indonesia.

British Broadcasting Coorporation. (2016, Mei 19). Sunat Perempuan di Indonesia, Tradisi atau Agama? (E. BBC, Penyunting) Diambil kembali dari https://www.bbc.com/indonesia/ majalah / $2016 / 05 / 160510_{-}$ indonesia_sunat_perempuan

CNN Indonesia. (2019, November 29). Keluarga Jelaskan Kronologi Atlet Dicoret karena Tak Perawan. (C. editorial, Penyunting) Dipetik Desember 10, 2019, dari www. cnnindonesia: https://www. cnnindonesia.com /olahraga/ 
20191129141921-178-452666/ keluarga-jelaskan-kronologi-atletdicoret-karena-tak-perawan

Foucault, M. (1997). Dicipline and Punish: The Birth of The Prison translation of Surveiler et Punir (2 ed.). (Gallimard, Penyunt.) New York, United Stated: Vintage Books.

Gamble, S. (2010). Pengantar Memahami Feminisme dan Postfeminisme Diterjemahkan dari The Routledge Companion to Feminism and Postfeminism (1 ed.). (S. Jamilah, Penyunt., \& T. P. Jalasutra, Penerj.) Yogyakarta, Indonesia: Jalasutra.

Hernawati. (2016, November). Sulsel Post. Diambil kembali dari Sulselprov. go.id: https://sulselprov.go.id/ welcome/post/peran-wanitasebagai-ibu-menurut-konsepsi-islam

Hogle, L. (2016, January 21). Enhancement Technologies and the Body. Article in Annual Review of Anthropology.

Hull, T. d. (2016, January 04). Male Circumcision and Penis Enhancement in Southeast Asia: Matter of Pain and Pleasuure. Journal of Reproductive Health matters, Vol. 9, No. $8,9$.

Kompas.com. (2013, Desember 4). Regional Kompas. Diambil kembali dari Kompas.com: https://regional. kompas.com/read/ Remaja.Putri. di.Surabaya.Marak.Operasi.Balik. Perawan.

Kumparan, R. (2018, Januari 18). Kumparan Travel. Diambil kembali dari Kumparan.com: https://kumparan. com/@kumparantravel/kerik-gigitradisi-menyakitkan-and-simbolkecantikan-suku-mentawai.

Mackenzie. (2017, Juli 3). Vagina Surgery Sought by Girl as Young as Nine. (V. Derbyshire, Penyunting) Diambil kembali dari BBC.com: http:/ / www. bbc.com/news/health-40410459.
MacKinnon, C. (1989). Sexuality, Pornography, and Method: Pleasure under Patriarchy. Chicago Journal, ed 2 vol.99, 314-346.

Mitchell, J. (2000). Psychoanalysis and Deminism: A Radical Reassessment of Freudian Psychoanalysis (4th ed ed.). United State of America: Penguin Books.

Nainggolan. (2017, Agustus 01). Metro TV News Kesehatan. Diambil kembali dari Metrotvnews.com: http:// rona.metrotvnews.com/kesehatan/ gNQ12onK-tren-mempercantikbagian-intim-makin-meningkat

Naomi, W. (2002). The Beauty Myth: Ho Images of Beauty Are Used Agains Women. new York, United States of America: HarperCollins Publishers.

National Geographic Indonesia. (2018). National Geographic Indonesia Grid. Diambil kembali dari Nationalgeographic.grid.id: https://nationalgeographic.grid. id/ read/13944776/lotus-feetmeremukkan-kaki-sebagai-simbolkecantikan-di-tiongkok.

Palung, R. (Sutradara). (2018). Kertas Merah (Film pendek). Jakarta: FFTV Institut Kesenian Jakarta. [Gambar Hidup]. Jakarta.

Pujiastuti, T. (2016, November 10). Lembaga Ilmu Pengetahuan Indonesia. (Pujiastuti, Tri) Diambil kembali dari http:/ /lipi.go.id/lipimedia/lipipenasaran-tradisi-petekan/16909

Rohmaitun, M. (2017). Hipwee Wedding. Diambil kembali dari Hipwee. com: https://www.hipwee.com/ wedding/jangan-pernah-remehkankami-yang-melahirkan-caesarnyatanya-risiko-yang-ditanggungleb

Syahri, M. (2015, November 26). Regional Kompas Cirebon . Diambil kembali dari Kompas.com: https://regional.kompas.com/ 
$\mathrm{read} / 2015 / 11 / 26 / 06300001 /$. Rangkaian.Bunga.Akan.Layu.kalau. Anak.Gadis.Tak.Perawan.Lagi.

Taylor, G. (2017, Mei 25). CNN Indonesia Gaya Hidup. Diambil kembali dari CNNIndonesia.com: https:// www.cnnindonesia.com/gayahidup/20170519010003-255-215867/ alasan-pentingnya-menjaga-areakewanitaan

Thornham, S. (2010). Teori Feminisme dan Cultural Studies Diterjemahkan dari Feminist Theory and Cultural Studies: Studies of Unsetted Relation (1 ed.). (S. Jamilah, Penyunt., \& B. Asma, Penerj.) Yogyakarta, Indonesia: Jala Sutra.

Udasmoro, W. (2004, Juni 2). Konsep Nasionalisme dan Hak Reproduksi Perempuan: Analisis Gender terhadap Program Keluarga
Berencana di Indonesia. Humaniora, 16 (2), 147-154.

Udasworo, W. (2017, Desember 2). Reproduksi Womanhood Dalam Novel Bunda: Kisah Cinta Dua Kodi Karya Asma Nadia. Adabiyyāt: Jurnal Bahasa dan Sastra, Vol. I, No. 2, 182200.

Wargadiredja, A. (2017, April). Vice Indonesia . Diambil kembali dari Vice.com: https://www.vice.com/id_id/ article/538745/meningkatnyatren-operasi-caesar-di-indonesiaberujung-dilema-bagi-perempuan.

Widyantoro, N. H. (2010, Februari). A Cross Cultural Study of Vaginal Practices and A Cross Cultural Study of Vaginal Practices and Sexuality: Implications for Sexual Health. 70(3), 392-400. 